\title{
Garment Size Systems and Pattern Construction
}

\author{
Jacqueline Domjanić and Darko Ujević* \\ Department of Clothing Technology, University of Zagreb, Croatia
}

Submission: June 20, 2018; Published: July 10, 2018

*Corresponding author: Darko Ujević, Faculty of Textile Technology, University of Zagreb, Prilaz baruna Filipovica 28a, Croatia, Email: darko.ujević@ttf.hr

\begin{abstract}
Many countries around the world developed standard garment sizing systems. The aim of a sizing system is to satisfy consumers in terms of identifying the size that fit their body for mass producted garments. Sizing systems differ from country to country because body shapes and proportions of consumers varies, even though improvement of appropriate sizing systems can result in better clothing function and customer satisfaction. Croatia also performed the compound technological project Croatian Anthropometric System (STIRP CAS) in order to define conditions for a new size system of clothing and footwear.
\end{abstract}

Keywords: Body measurements; Anthropometry; Standardization of apparel sizes

\section{Introduction}

Two-dimensional patterns are considered as a basis for garment development, and are made through different pattern construction methods developed by numerous experts over many years. Traditional pattern construction techniques are known as drafting a basic block pattern, flat pattern or modelling on the dress stand particularly in conture design. To improve efficiency pattern makers use standard sizes and measurements to draft basic patterns. Garment patterns are drafted for one size that is usually a size in the middle range, and this pattern is than scaled up and downfor smaller and larger sizes. Over the years, clothing manufacturers have faced issues how to improve and create optimal fit for ready-to-wear garments. A common solution was to develop a sizing system and incorporate body information into the desired patterns. The aim of a sizing system is to satisfy consumers in terms of identifying the size that fit their body for mass producted garments [1-4]. Anthropometry as anthropological method deals with the measurement of size, weight, and proportions of the human body. Procedures, methods and instruments for anthropometry are developed in such a way to make valid and reliable measurements of individual subjects, regions and populations needed for garment construction and design [5]. Numerous anthropometric studies are available in order to acquire information about body size and proportions of a certain population. Sizing systems differ from country to country because body shapes and proportions of consumers varies [1-7].

\section{Development of sizing standards}

After tailors and pattern makers from the garment industry requested a international sizing system, the International Standardization Organization (ISO) submitted in 1979 a document entitled ISO 8559,,Garment Construction and Anthropometric Surveys - Body Dimension" as the international standard for all kinds of garment size surveys. This international standard suggests to describe garment sizes as a pictogram that symbolically display a silhouette of human body measurements with theappertaining description (body measurements are on the left side (horizontal) and shows the measuring point of an individual measurement shown in (Figure $1 \mathrm{a} \& 1 \mathrm{~b}$ ) $[8,9]$.

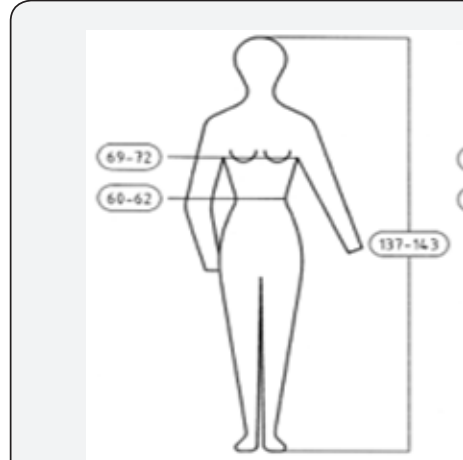

a)

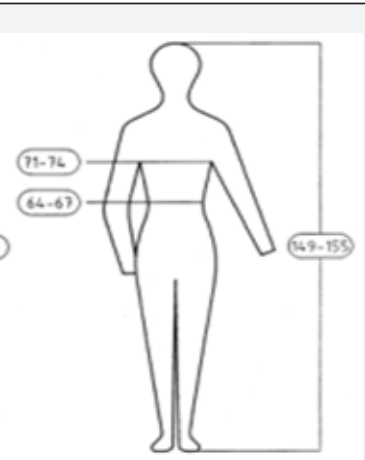

b)
Figure 1: Example of pictograms for: a) girls and b) young men[9]. 
Many countries around theworld developed standard garment sizing systems such as: ISO garment sizing system, German sizing system, European, American, Japanese, Korean,Chinese garment sizing system and so on [3]. Those standards classified given range of measurements into several body types with similar body mesurements. Croatia also performed the compound technological project Croatian Anthropometric System (STIRP CAS) in order to define conditions for a new size system of clothing and footwear. The project included anthropometric measurements of the population in 20 Croatian counties and in the city of Zagreb within the age group from 20 to 70 years divided in six age groups. After statistical analysis seven types of women's body were determined based on the difference between bust circumference and hip circumference, while nine men's body types were determined based on the difference between chest and waist difference [9].

\section{Conclusion}

Garment manufactures use standard garment sizing systems in order to improve design and production of apparel. Due to the wide variation in body dimensions and body shapes, it is difficult to achieve an international garment size system. However, understanding of human body shapes is essential in pattern making and even though development of sizing systems are a complex process, improvement of appropriate sizing systems can result in better clothing function and customer satisfaction.

\section{References}

1. Watkins P (2011) Garment pattern design and comfort. In: Song G (2011) Improving Comfort in Clothing. (1st ed.) Woodhead Publishing Series in Textiles, Cambridge, UK, pp. 245-273.

2. Stiegler M, Krolopp L (2012) Metric Patternmaking for skirts and troursers. ( $1^{\text {st }}$ ed.) Deutsche Bekleidungs-Akademie Munchen, Munchen, Germany, pp. 1-186.

3. Chun J (2011) International apparel sizing systems and standardization of apparel sizes. In: Song G Improving Comfort in Clothing. ( $1^{\text {st }}$ ed.) Woodhead Publishing Series in Textiles, Cambridge, UK, pp. 274-304.

4. Watkins SM, Dunne LE (2015) Functional Clothing Design: from Sportswear to spacesuits. ( $3^{\text {rd }}$ ed.) Bloomsbury Publishing Inc, New York, USA, pp. 31-88.

5. Ujević D, Szirovicza L, Karabegović I (2005) Anthropometry and the Comparison of Garment Size Systems in Some European Countries. Collegium Antropologicum 29(1): 71-78.

6. Ujević D, Domjanić Ž, Rogina-Car B (2008) Proceedings of the 4th International Textile, Clothing \& Design Conference 2008 - Magic World of Textiles, Croatia.

7. Ashdown SP (2007) Sizing in clothing ( $1^{\text {st }}$ edn.) Woodhead Publishing Limited and CRC Press LLC, Boca Raton, USA, 1-407.

8. Ujević (2010) Contribution to the determination and designation of garment sizes In: Theoretical Aspects and Application of Croatian Anthropometric System. (1st ed.) Faculty of Textile Technology, Cakovec, Croatia pp. 83-88.

9. Ujević (2010) Contribution to the support data for new Croatian standard for garment and footwear size and their designation In: Theoretical Aspects and Application of Croatian Anthropometric System. ( $1^{\text {st }}$ ed.) Faculty of Textile Technology, Cakovec, Croatia pp. 282-305.

\section{Your next submission with Juniper Publishers will reach you the below assets}

- Quality Editorial service

- Swift Peer Review

- Reprints availability

- E-prints Service

- Manuscript Podcast for convenient understanding

- Global attainment for your research

- Manuscript accessibility in different formats

( Pdf, E-pub, Full Text, Audio)

- Unceasing customer service

Track the below URL for one-step submission https://juniperpublishers.com/online-submission.php 